\title{
Pemilihan Moda Dan Preferensi Angkutan Umum Khusus Perempuan Di Kota Bandar Lampung Fera Lestari ${ }^{(1)}$, Ahmad Ari Aldino ${ }^{(2)}$ \\ ${ }^{(\mathbf{1}, 2)}$ Fakultas Teknik dan Ilmu Komputer, Universitas Teknokrat Indonesia
}

\begin{abstract}
Abstrak
Maraknya kriminalitas yang terjadi di angkutan umum membuat citra angkutan umum semakin buruk terutama bagi para perempuan yang rentan menjadi sasaran kriminal tersebut terlebih lagi sebagian besar pengguna angkutan umum adalah perempuan. Oleh karena itu perlu adanya inisiatif untuk kebijakan transportasi yang melihat dari prespektif gender baik dalam perencanaan dan implementasinya. Upaya ini juga dilakukan untuk membantu pemerintah dalam mengajak masyarakat untuk lebih memilih menggunakan angkutan umum. Penelitian ini bertujuan untuk mengetahui karakteristik perilaku perjalanan oleh perempuan dan memperoleh probabilitas pelaku perjalanan dalam memilih moda angkutan umum khusus perempuan Metode penelitian dalam penelitian ini adalah deskriptis analitis diamana menggambarkan suatu peristiwa kemudian melakukan analisis terhadap masalah yang timbul. Hasil menunjukkan bahwa terdapat hubungan antara pemilihan moda untuk melakukan perjalanan oleh perempuan dengan faktor sosio demografi serta terdapat hubungan antara pemilihan moda dengan tujuan perjalanan yang dilakukan oleh perempuan. Probabilitas untuk pemilihan moda angkutan umum khusus perempuan mungkin akan dipilih sebagai moda yang digunakan untuk melakukan perjalanan oleh perempuan cukup tinggi. Sehingga diharapkan dengan adanya angkutan khusus perempuan dapat menjadii salah satu solusi dari permasalahan transportasi khususnya masalah yang sering dialami oleh perempuan. Angkutan umum khusus perempuan mungkin untuk diladakan. Namun, perlu kajian lebih dalam diantaranya mengenai keinginan dan kemampuan untuk membayar serta rancangan mengenai jumlah armada, trayek, tarif angkutan dan lainnya.
\end{abstract}

Keywords : angkutan umum, perempuan, pemilihan moda, karakteristik perilaku perjalanan

\section{Pendahuluan}

Sangat disadari bahwa moda angkutan umum jauh lebih efisien daripada moda angkutan pribadi. Tidak mungkin menampung semua kendaraan pribadi di suatu kota karena dibutuhkan ruang jalan yang sangat luas dan tempat parkir. Permasalahan yang timbul akibat tingginya permintaan transportasi diharapkan dapat diatasi dengan adanya angkutan umum. Penggunaan angkutan umum di Bandar Lampung mengalami penurunan dimana tahun 2011 sebesar 12,23\% sedangkan tahun 2015 sebesar $5,93 \%$. Penurunan penggunaan angkutan umum terus terjadi hingga $0,3 \%$ per tahunnya (Malik,2017). Penurunan angka ini dapat disebabkan oleh penurunan pelayanan angkutan umum. Padahal prioritas utama dalam mewujudkan layanan kendaraan umum bagi penumpang adalah keamanan bagi penumpangnya (Prihono, 2011)

Survei tentang keamanan transportasi umum pada 2016 oleh The Thomson Reuters Foundation bersama lembaga survei YouGov terhadap lebih dari 6.550 perempuan dari 15 kota besar di dunia menempatkan Jakarta berada di peringkat kelima di dunia sebagai kota yang memiliki transportasi tidak aman untuk perempuan. Data dari Polda Metro Jaya menyebutkan selama tahun 2011 terjadi 68 kasus pemerkosaan di Jakarta, naik sekitar 13,33 persen dibandingkan tahun 2010. Sedangkan data Komnas
Perempuan menunjukkan kasus pemerkosaan di tempat umum tercatat sebanyak 22.285 kasus, diantaranya pada awal tahun lalu marak pemerkosaan di angkutan kota Perempuan melakukan lebih banyak perjalanan per hari tetapi menempuh jarak yang lebih pendek dibandingkan laki-laki.(Olde Kalter et al, 2009). Tahun 2007 di Amerika Serikat, 55\% penumpang angkutan umum adalah perempuan. Di Prancis, dua pertiga penumpang angkutan umum adalah perempuan (Duchène, 2011). Di Indonesia seperti Jakarta khususnya busway, proporsi penumpang perempuan sebesar $55 \%$, sementara proporsi penumpang lakilaki sebesar $45 \%$ (Murdiono, 2006). Pola perjalanan yang dilakukan oleh perempuan berbeda dari lakilaki. Perbedaan ini terkait dengan ketidaksetaraan gender di dalam rumah, pasar tenaga kerja, struktur perkotaan, proses sosialisasi dan pendidikan.

Hasil studi yang dilakukan oleh Badan PBB untuk Kesetaraan Gender dan Pemberdayaan Perempuan (UN Women), perempuan merasa tidak aman karena lebih rentan menjadi korban pelecehan dan kekerasan seksual di tempat umum, termasuk di transportasi publik. Dengan memperbaiki kualitas dan kondisi angkutan umum diharapkan tercipta angkutan umum yang handal, aman dan nyaman. Perempuan akan lebih tertarik tetap menggunakan transportasi umum di masa depan apabila tingkat 
kenyamanan pada sistem transportasi umum ditingkatkan (Fu, 2017)

Citra angkutan umum yang buruk membuat orang enggan memilih angkutan umum sebagai moda transportasi untuk melakukan perjalananya, padahal angkutan umum merupakan salah satu cara dalam mewujudkan lau lintas yang aman, nyaman dan berkelanjutan. Maraknya kriminalitas yang terjadi di angkutan umum membuat citra angkutan umum semakin buruk terutama bagi para perempuan yang rentan menjadi sasaran kriminal tersebut terlebih lagi sebagian besar pengguna angkutan umum adalah perempuan. Oleh karena itu perlu adanya inisiatif untuk kebijakan transportasi yang melihat dari prespektif gender baik dalam perencanaan dan implementasinya. Upaya ini juga dilakukan untuk membantu pemerintah dalam mengajak masyarakat untuk lebih memilih menggunakan angkutan umum.

Penelitian ini bertujuan untuk mengetahui karakteristik perilaku perjalanan oleh perempuan dan memperoleh probabilitas pelaku perjalanan dalam memilih moda angkutan umum khusus perempuan

\section{Metode}

Metode penelitian yang digunakan adalah deskriptis analitis yaitu menggambarkan suatu peristiwa kemudian melakukan analisis masalah yang timbul. Metode analisa data yang dilakukan dalam studi ini adalah menghitung data perhitungan dari hasil survei (kuisioner). Dari kuisioner yang diberikan kepada penumpang akan diperoleh data karakteristik penumpang dan peluang penumpang terhadap moda transportasi yang direncanakan. Untuk mendapatkan karakteristik dari perilaku perjalanan yang dilakukan oleh perempuan dilakukan pengelompokan data dengan menggunakan distribusi frekuensi. Sedangan untuk mengetahui hubungan antara pemilihan moda dengan factor sosio demografi dan tujuan perjalanan digunakan analisis ststistik dengan menggunakan uji chi square.

Jumlah sampel minimal yang harus diambila adalah sebanyak 100 orang (Margono, 2010) penetapan besar kecilnya sampel tidaklah ada suatu ketetapan yang mutlak, artinya tidak ada satupun ketentuan berapa persen suatu sampel harus diambil. Pengambilan sampling dalam penelitian ini merupakan gabungan antara teknik sampling aksidental dengan purposivel judgement sampling. Metode sampling aksidental adalah teknik penentuan sampel berdasarkan kebetulan, yaitu siapa saja yang secara kebetulan bertemu dengan peneliti dapat digunakan sebagai sampel, bila dipandang orang yang kebetulan ditemui tersebut cocok sebagai sumber data. Sedangkan purposive/ judgement sampling adalah teknik penentuan sampling yang dipilih berdasarkan tujuan penelitian, yaitu sampel data berdasarkan karakteristik tertentu yang berkaitan dengan penelitian.

\section{Hasil dan Pembahasan}

Pengambilan data dilakukan dengan cara memberikan kuisioner kepada responden, Jumlah respon yang diterima dari kuisioner yang dibagikan secara online didapatkan respon dari 104 responden.

Dalam rangka mengurangi permintaan perjalanan perlu dilakukan beberapa alternatif yang harus dilakukan. Terwujudnya transportasi yang aman dan nyaman bagi penggunanya merupakan hal yang diharapkan ada dalam sebuah sistem transportasi. Dibutuhkan perencanaan dan perancangan transportasi yang tepat dan didukung dengan adanya kebijakan-kebijakan untuk mewujudkan sistem transportasi yang aman, nyaman, ekonomis dan berkelanjutan. Untuk melakukan hal tersebut dibutuhkan suatu data diantaranya data mengenai karakteristik perilaku perjalanan.

Data yang dihasilkan dari distribusi frekuensi mengenai karakteristik perilaku perjalanan diuraikan sesuai dengan karakteristiknya diantaranya karakteristik moda, usia, pendidikan, pendapatan, pekerjaan dan kepemilikan kendaraan.

Moda perjalanan merupakan salah satu karakteristik dalam melakukan perjalanan. Pemilihan moda yang dilakukan oleh perempuan di Kota Bandar Lampung terdiri dari kendaraan umum dan kendaraan pribadi, Kendaraan umum terdiri dari angkutan umum dan ojek online sedangkan untuk kendaraan pribadi yaitu berupa sepeda motor dan mobil. Selain dengan penggunaan kendaraan ada pula yang memilih berjalan kaki dalam melakukan perjalananya.

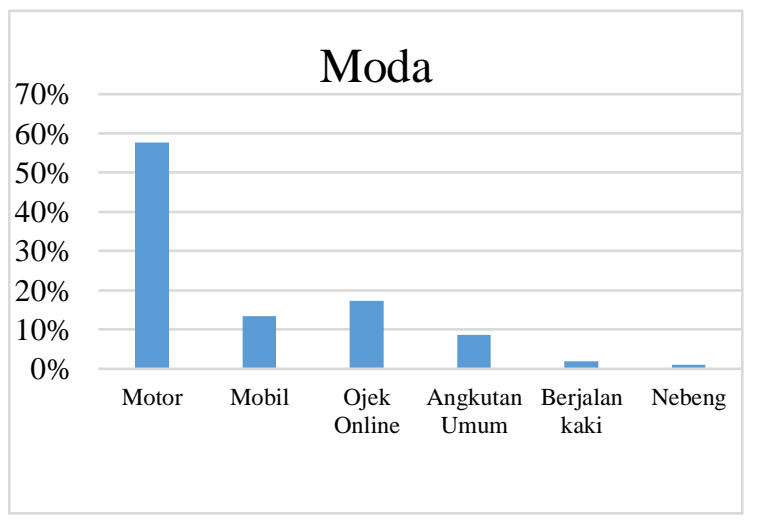

Gambar 1. Karakteristik Moda

Berdasarkan kuesioner yang telah disebar kepada responden di Kota Bandar Lampung moda perjalanan yang digunakan untuk melakukan kegiatan oleh perempuan adalah 60 orang menggunakan sepeda motor $(57,69 \%), 14$ orang menggunakan mobil $(13,46 \%), 18$ orang menggunakan Ojek Online $(17,30 \%), 9$ orang 
menggunakan angkutan umum (8,65\%), 2 orang berjalan kaki $(1,9 \%)$ dan 1 orang menebeng $(1 \%)$

\section{Usia}

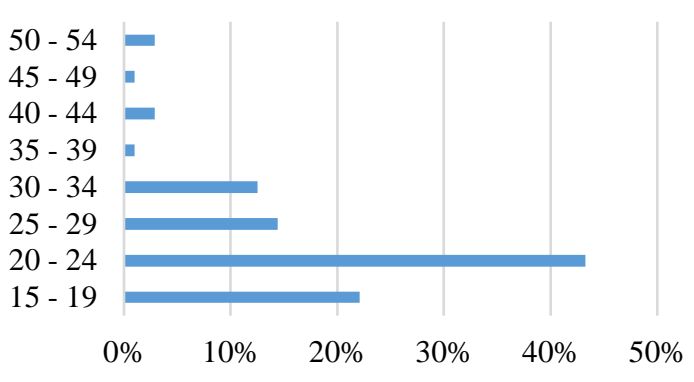

Gambar 2. Karakteristik Usia

Karakteristik usia dari perilaku perjalanan oleh perempuan ditunjukkan pada gambar 2. Kelompok usia perempuan yang melakukan perjalanan terbesar terdapat pada kelompok usia 20-24 sedangkan kelompok usia yang melakukan perjalanan paling sedikit adalah kelompok usia 35-54 tahun. Rincian dari karakteristik usia ditunjuukkan pada Gambar 2.

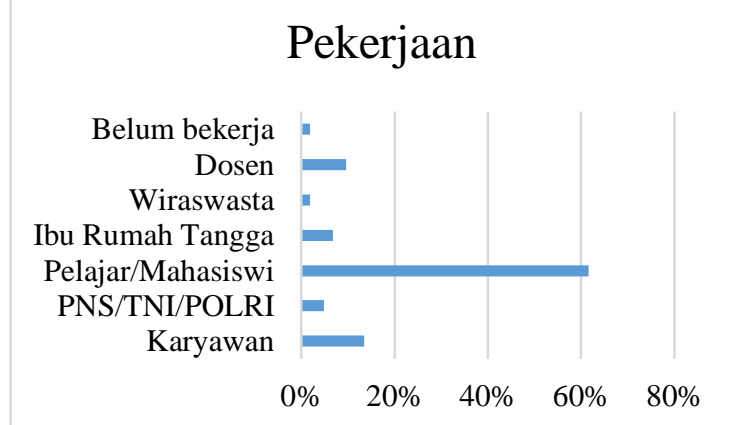

Gambar 3. Karakteristik Pekerjaan

Karakteristik pekerjaan dari perempuan dalam melakukan perjalanan ditunjukkan oleh gambar 3 . Hasil dari kuisioner menunjukkan bahwa sebanyak 64 orang (62\%) merupakan pelajar/mahasiswa. Sebanyak 14 orang (13\%) bekerja sebagai karyawan, 10 orang (10\%) bekerja sebagai dosen, 7 orang $(7 \%)$ bekerja sebagai ibu rumah tangga, 5 orang bekerja sebagai PNS/TNI/POLRI, 2 orang ( $2 \%)$ wiraswasta dan 2 orang $(2 \%)$ belum bekerja.

\section{Pendidikan}

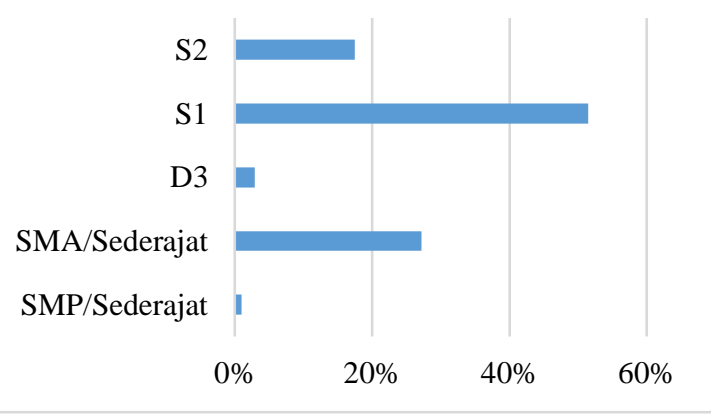

Gambar 4. Karakteristik Pendidikan
Gambar 4. menunjukkan karakteristik pendidikan dari perilaku perjalanan khusunya oleh perempuan. Karakteristik pendidikan tertinggi ditunjukkan dengan pendidikan S1 sebanyak 53 orang (51\%). Karakteristik pendidikan lainnya yaitu sebanyak 28 orang $(27 \%)$ berpendidikan SMA/sederajat, 18 orang (17\%) berpendidkan S2, sebanyak 3 orang (3\%) berpendidikan D3 dan 1 orang $(1 \%)$ berpendidikan SMP/Sederajat.

Karakteristik lainnya dari perilaku perjalanan oleh perempuan adalah penghasilan. Hasi dari kuisioner menunjukkan bahwa sebanyak 62 orang (60\%) belum berpenghasilan.

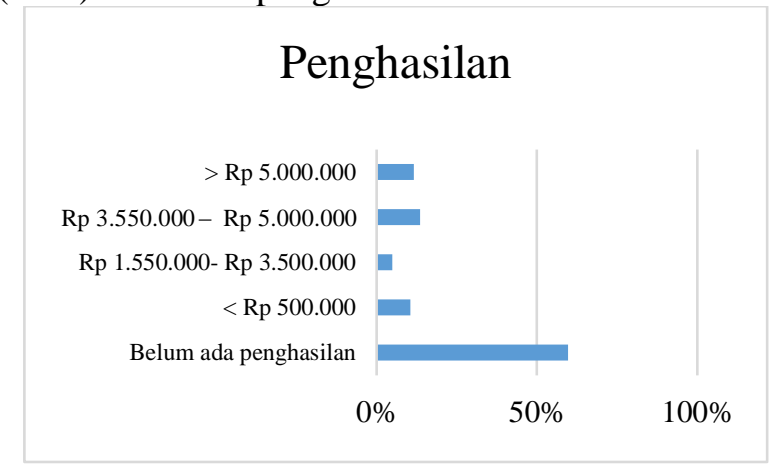

Gambar 5. Karakteristik Penghasilan

Sebanyak 14 orang (13\%) memiliki pendapatan Rp 3.550.000 - Rp 5.000.000, sebanyak 12 orang (11\%) memiliki pendapatan < Rp 500.000, sebanyak 12 orang (12\%) memiliki pendapatan > Rp 5.000.000 dan sebanyak 5 orang (5\%) memiliki pendapatan $\mathrm{Rp} \quad 1.550 .000-\mathrm{Rp} \quad 3.500 .000$. karakteristik penghasilan ditunjukkan pada Gambar 5.

\section{Kepemilikan Kendaraan}

Tidak memiliki kendaraan

Mobil

Motor

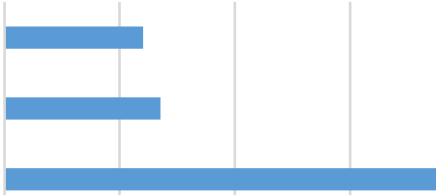

$\begin{array}{lllll}0 & 20 & 40 & 60 & 80\end{array}$

Gambar 6. Karakteristik Kepemilikan Kendaraan

Karakteristik kepemilikan kendaraan ditunjukkan pada Gambar 6 Berdasarkan hasil kuisioner terdapat sebanyak 75 memiliki motor, 27 orang memiliki mobil dan sebanyak 24 orang tidak memiliki orang kendaraan.

Kepemilikan motor dan kepemilikan mobil ditunjukkan pada Gambar 7 dan Gambar 8 


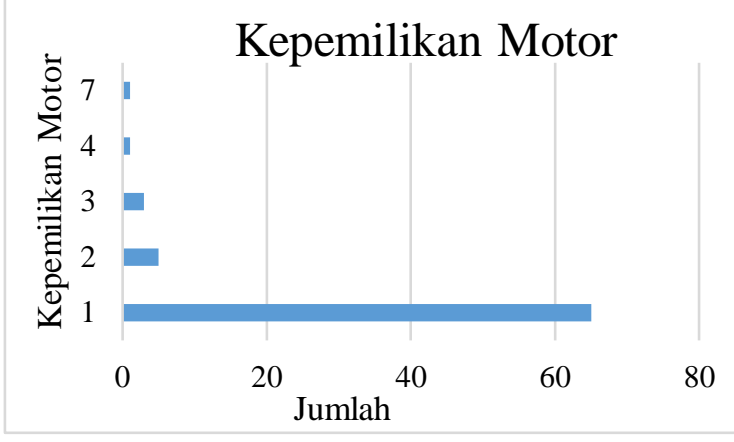

Gambar 7. Kepemilikan Motor

Hasil dari kuisioner menunjukkan untuk kepemilikan motor, sebanyak 65 orang memiliki 1 motor, responden yang memiliki 2 motor sebanyak 5 orang, responden yang memiliki 3 motor berjumlah 3 , yang memiliki 4 motor sebanyak 1 orang dan yang memiliki 7 motor sebanyak 1 orang.

Data mengenai karakteristik kepemilikan mobil ditunjukkan pada Gambar 8 Untuk responden dengan kepemilikan 1 mobil berjumlah 23 orang, untuk kepemilikan 2 mobil sebanyak 4 orang dan untuk kepemilikan 6 mobil sebanyak 1 orang.

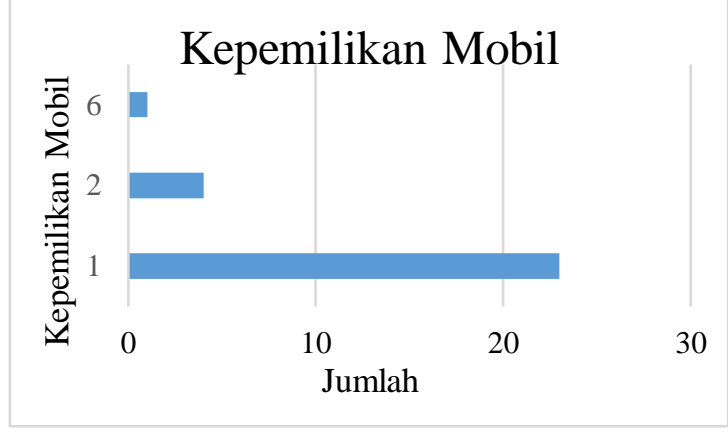

Gambar 8. Kepemilikan Mobil

Setelah diketahui karakteristik perjalanan yang dilakukan oleh perempuan dilakukan analisis terhadap hubungan antara pemilihan moda dengan faktor sosio demografi (usia, pendidikan, pekerjaan, dan kepemilikan kendaraan). Selain itu analisis korelasi juga dilakukan antara pemilihan moda dengan tujuan perjalanan. Untuk mengetahui hubungan atau korelasi dari pemilihan moda dengan faktor sosio demografi (usia, pekerjaan, kepemilikan kendaraan) dan hubungaan antara pemilihan moda dengan tujuan perjalan dilakukan analisis statistik berupa analisis chi square. Signifikansi 0,01 menunjukan bahwa tingak kepercayaan data sebesar 99\% Adanya hubungan dari variabel bebas dan variabel terikat yang diuji ditunjukan dengan signifikansi yang memiliki nilai kurang dari 0,05 .

Terdapat hubungan antara pemilihan penggunaan mobil pribadi dengan usia, Pendidikan SMP dan S2, pekerjan sebagai dosen dan ibu rumah tangga dan jumlah kepemilikan mobil. Hubungan antara pemilihan moda berupa mobil pribadi dengan pekerjaan sebagai mahasiswa/pelajar menunjukan angka negatif yang artinya jika pekerjaannya pelajar/mahasiswa maka semakin tidak menggunkan mobil pribadi.

Tabel 2. menunjukkan hubungan antara pemilihan moda terhadap tujuan perjalanan. Terdapat hubungan antara pemilihan penggunaan mobil pribadi dengan tujuan perjalanan belanja \& bekerja dan belanja \& kunjungan kerabat. Selain itu terdapat hubungan antara pemilihan moda Tabel 2. menunjukkan hubungan antara pemilihan moda terhadap tujuan perjalanan. Terdapat hubungan antara pemilihan penggunaan mobil pribadi dengan tujuan perjalanan belanja \& bekerja dan belanja \& kunjungan kerabat. Selain itu terdapat hubungan antara pemilihan moda

Tabel 1. Hubungan Antara Pemilihan Moda Dengan Faktor Sosiodemografi

\begin{tabular}{lcc}
\hline \multicolumn{1}{c}{ Hubungan Korelasi } & $\begin{array}{c}\text { Pearson } \\
\text { Correlation }\end{array}$ & Significant \\
\hline Usia dengan Mobil Pribadi & 0,345 & 0,000342 \\
Pendidikan S2 dengan Mobil Pribadi & 0,254 & 0,0004 \\
Pendidikan SMP dengan Mobil Pribadi & 0,25 & 0,010538 \\
Dosen dengan Mobil Pribadi & 0,254 & 0,009387 \\
Ibu Rumah Tangga dengan Mobil Pribadi & 0,344 & 0,000353 \\
Pelajar/ Mahasiswa dengan Mobil Pribadi & $-0,441$ & 0,000003 \\
Jumlah Mobil dengan Mobil Pribadi & 0,549 & 0,000 \\
\hline
\end{tabular}

angkutan umum dengan tujuan perjalanan berbelanja kunjungan sekolah kunjungan kerabat dan ada hubungan antara tujuan perjalanan kunjungan kerabat dengan pemilihan moda jalan kaki dan nebeng. 
Tabel 2. Hubungan Antara Pemilihan Moda Dengan Tujuan Perjalanan

\begin{tabular}{lcc}
\hline \multicolumn{1}{c}{ Hubungan Korelasi } & $\begin{array}{c}\text { Pearson } \\
\text { Correlation }\end{array}$ & Significant \\
\hline Belanja \& Bekerja dengan Mobil Pribadi & 0,254 & 0.009387 \\
Belanja \& Kunjungan Kerabat dengan Mobil Pribadi & 0,269 & 0.005823 \\
Belanja, Kunjungan Kerabat, Sekolah dengan angkutan umum & 0,455 & 0.000001 \\
Kunjungan Kerabat dengan Jalan Kaki & 0,394 & 0.000035 \\
Kunjungan Kerabat dengan Nebeng & 0,572 & 0,0000023 \\
\hline
\end{tabular}

Tabel 3. Probabilitas Angkutan Khusus Perempuan

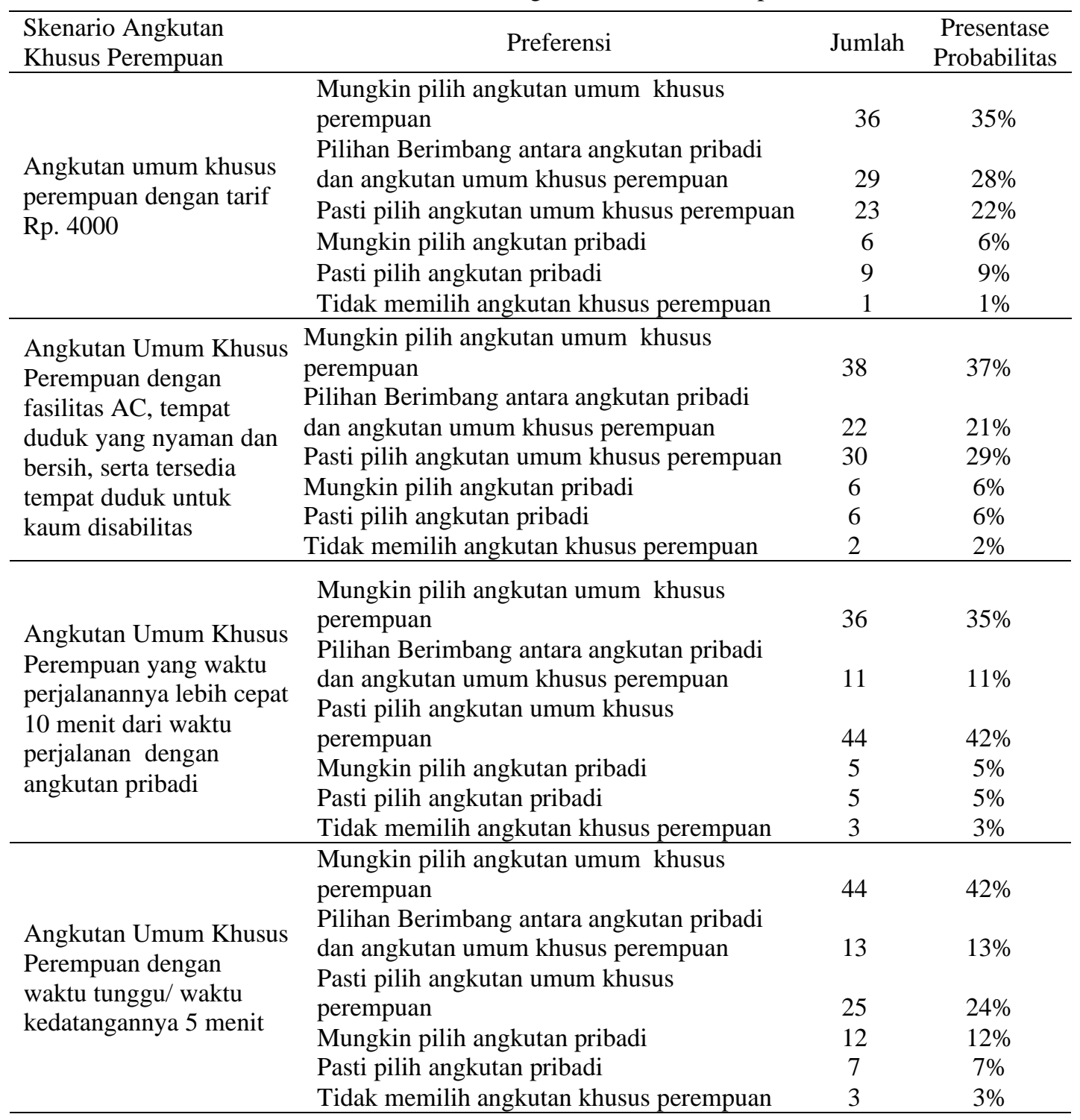

\section{Kesimpulan}

Dari hasil yang analisis data maka dapat ditarik kesimpulan bahwa terdapat hubungan antara pemilihan moda untuk melakukan perjalanan oleh perempuan dengan faktor sosio demografi serta terdapat hubungan antara pemilihan moda dengan tujuan perjalanan yang dilakukan oleh perempuan.

Probabilitas untuk pemilihan moda angkutan umum khusus perempuan mungkin akan dipilih sebagai moda yang digunakan untuk melakukan perjalanan oleh perempuan. Hal ini ditunjukkan dari hasil kuisioner dimana responden lebih banyak memilih jawaban mungkin naik angkutan umum khusus perempuan dan pasti pilih angkutan umum khusus perempuan. Sehingga diharapkan dengan adanya angkutan khusus perempuan dapat menjadii salah satu solusi dari permasalahan transportasi khususnya masalah yang sering dialami oleh perempuan. Angkutan umum khusus perempuan mungkin untuk diladakan. Namun, perlu kajian lebih dalam diantaranya mengenai keinginan dan kemampuan untuk membayar serta rancangan mengenai jumlah armada, trayek, tarif angkutan dan lainnya 


\section{Ucapan Terimakasih}

Terima kasih penulis sampaikan kepada Kementerian Riset dan Teknologi/ Badan Riset dan Inovasi Nasional yang telah memberikan dana hibah penelitian sesuai Kontrak Penelitian Tahun Anggaran $2020 \quad$ Nomor: 839/SP2H/LT/MONO/LL2/ 20202 Tanggal 24 Juni 2020. Selanjutnya, terima kasih kepada ketua dan staff LPPM Universitas Teknokrat Indonesia yang telah memfasilitasi kegiatan PDP.

\section{Daftar Pustaka}

Cornish, D. and Clarke, R. 1987. Understanding Crime Displacement: An Application of rational choice theory. Criminology

Duchène, Chantal, 2011. Germany.Gender and Transport. International Transport Forum, Leipzig.

$\mathrm{Fu}$, Xuamei. 2017. Exploring the Psychosocial Factors Associated with Public Transportation Usage and Examining the Gendered Difference.

Malik, Ida Bagus Ilham. 2017. Dari 1,4 Juta Penduduk Bandar Lampung Hanya 87 Ribu Pengguna Angkutan Umum .Center for Urban and Regional Studies. Universitas Bandar Lampung

Margono, S., (2010). Metodologi Penelitian Pendidikan. Rineka Cipta.Jakarta. $259 \mathrm{hlm}$

Murdiono, Jatmiko, 2006. Persepsi Konsumen Terhadap Pelayanan Busway Trans Jakarta, Jurnal Ekubank, 3.

Olde-Kalter, Marie-Jose, Lucas Harms and Peter Jorristma. 2009. Changing Travel Patterns of Women in the Netherlands. 31st Iatur Conference of the International Association for Time Use Research.

Prihono, 2011. Disain Layanan Kendaraan Umum untuk Wanita Berbasis Fuzzy-Kano Quality Function Development (QFD), Tesis Magister Teknik Institut Teknologi Sepuluh 